\title{
Chemical Attributes of a Dystrophic Red Latosol of Brazilian Cerrado After Poultry Litter Application Associated to a Urea Inhibitor
}

\author{
Joiran Luiz Magalhães ${ }^{1,2,4}$, Antonio Carlos Saraiva da Costa ${ }^{2}$, June Faria Scherrer Menezes ${ }^{1}$, \\ Elcio Barbosa De Oliveira ${ }^{1,2}$, Marcos Vinicius Pereira Vieira ${ }^{1}$, Daniela Borges do Couto Magalhães ${ }^{4}$ \\ $\&$ Arthur Almeida Rodrigues ${ }^{3}$ \\ ${ }^{1}$ Universidade de Rio Verde, Rio Verde, Goiás, Brazil \\ ${ }^{2}$ Departamento de Agronomia, Universidade Estadual de Maringa, Maringá, Paraná, Brazil \\ ${ }^{3}$ Goiano Federal Institute of Education, Science and Technology, Campus Rio Verde, Rio Verde, Goiás, Brazil \\ ${ }^{4}$ Prefeitura de Rio Verde, Goiás, Secretaria Municipal de Educação, Rio Verde, Goiás, Brazil \\ Correspondence: Antonio Carlos Saraiva da Costa, Departamento de Agronomia, Universidade Estadual de \\ Maringá, Av. Colombo, Jd Universitario, nº 5790, ZIP 87020-900, Maringá, PR, Brazil. Tel: 55-44-3011-8944. \\ E-mail: antoniocscosta@gmail.com
}

Received: November 5, 2018

Accepted: December 8, 2018

Online Published: February 15, 2019

doi:10.5539/jas.v11n3p208

URL: https://doi.org/10.5539/jas.v11n3p208

\begin{abstract}
Poultry waste recycling is now a globally practice consolidated in agriculture. However, the proper disposal of poultry waste should enable to reduce $\mathrm{N}$ losses and to decrease pollution potential from the high concentrations of poultry litter applied to soil. In this context, the aim of the present study was to evaluate poultry litter doses and the effect of an urease inhibitor on the chemical attributes of a dystrophic Red Latosol. Two experiments were carried out, one in a greenhouse and another in a eucalyptus forest area, both applying completely randomized design with a $2 \times 6+1$ factorial arrangement, applying two types and six doses of poultry litter (5, $10,20,40,80$ and $160 \mathrm{t} \mathrm{ha}^{-1}$ ) plus the controls, with four replicates, total of 52 pots. The application of poultry litter doses altered soil chemical attributes, except for potential acidity. Soil $\mathrm{pH}$, cation exchange capacity (CEC), sum of bases (SB) and electric conductivity (EC) values and $\mathrm{Ca}, \mathrm{Mg}, \mathrm{K}, \mathrm{P}, \mathrm{S}$, organic matter (OM), Mn, Zn and $\mathrm{Cu}$ levels increased with increasing poultry litter doses, while Fe and B contents decreased. The 40, 80 and $160 \mathrm{t}$ $\mathrm{ha}^{-1}$ poultry litter doses led to contamination potential of the soil due to salinity and alkalinity, and also raised the EC of the percolate at levels limiting to plants. The NBPT (N-butyl thiophosphoric triamide) urease inhibitor exhibited no influence on soil chemical attributes.
\end{abstract}

Keywords: additive, chemical conditioner, appropriate destination, organic residues

\section{Introduction}

The use of urban, agricultural and industrial wastes as complements to chemical fertilizers in agriculture is a well-established practice (Lupton, 2017). The composition, organic matter, macro and micronutrient contents in organic residues, such as vinasse, poultry litter, liquid pig slurry, animal wastes, when properly handled, can constitute excellent soil chemical conditioners (Melo et al., 1994).

Poultry production is of note in this context, as it is one of the largest and quickest growing sectors of the agri-food industry worldwide. Considerable amounts of waste are generated in this process, and their correct destination is a problem (Inal et al., 2015, Hersztek \& Bara, 2016). Poultry litter recycling as a chemical soil conditioner has been practiced in many countries (Mello \& Vitti, 2002; Menezes et al., 2004), but the effects of these residues on soil chemical atributes, mainly at high doses, should be evaluated. However, a lack of studies in the central-western region of Brazil, in the wide area characterized as the Cerrado and in soils classified as Latosols, is observed (Gomes et al., 1994; Fontes et al., 2001). These soils present a high degree of weathering, are usually acidic, display low cation exchange capacity (CEC) that depends on soil $\mathrm{pH}$ and soil organic matter content, since they exhibit reduced natural fertility (Mendonça et al., 2006).

The application of poultry litter to these soils may be a solution to several frequently discussed issues, such as managing this type of material, improving physical, chemical and biological soil attributes and increasing organic matter and nutrient contents (Fontes et al., 2001; Arthur et al., 2015). However, high poultry litter 
availability at low costs can induce its application in excessive amounts, extrapolating plant nutritional requirements, whereas chemical fertilizers are cost-rationed (Ritter \& Chirnside, 1987). Some studies report the contaminating action of poultry residues in soil when applied in high amounts, leading to alkalinization, increases in electrical conductivity as a function of salinization (Schindler, 1978; Kingery et al., 1993; Bissani et al., 2004) and nutritional disturbance in crops due to excess $\mathrm{N}$ (Buijsman et al., 1987). In addition, the presence of excess chemical elements, such as copper and zinc, can lead to toxic effects in plants. Thus, the impacts of organic residue application on soil attributes depend on the initial residue constituents, and should be better investigated before residue application (Gaind \& Nain, 2010; Omari et al., 2016), obtaining maximum supplementation benefits to soil and plant attributes. Pearson's correlation coefficients and pedotransfer functions can be used to estimate soil attributes harder to obtain from simpler ones, have been used in studies on residue-fertilized soils (McBratney et al., 2002).

Poultry litter disposal and stocking have become an environmental problem, since they are associated to air, water and soil pollution. High ammonia concentrations cause adverse effects on poultry health and productivity, as well as on the health of workers that work in poultry houses (Cavallari et al., 2015). In order to take advantage of nitrogen $(\mathrm{N})$ and other nutrients contained in poultry litter, this residue has been used as a substitute for mineral fertilization (Zahan et al., 2018). However, much of the $\mathrm{N}$ available in the litter may be lost by volatilization, and compounds that inhibit this process are required (Termeer \& Warman, 1993).

The high $\mathrm{N}$ levels that might be released by organic residues should be emphasized (Cavalaglio et al., 2017). Nitrogen losses by volatilization and leaching might lead to eutrophication of water bodies, groundwater contamination and air pollution, also contributing to global warming by forming greenhouse gases (Heij \& Schneider, 1995; Cameron et al., 2013). The N source and type of fertilizer can significantly influence N losses and gaseous emissions. A variety of products have been developed to minimize $\mathrm{N}$ loss due to ammonia $\left(\mathrm{NH}_{3}\right)$ volatilization, such as urease inhibitors (Engel et al., 2011; Soares et al., 2012). These compounds temporarily inhibit urease activity and control $\mathrm{N}$ release in the soil-water matrix, allowing for better synchronization between $\mathrm{N}$ supplies and crop demands, minimizing gaseous losses of applied N (Soares et al., 2012; Turner et al., 2010).

The lack of information on soil chemical attribute alteration potential by poultry litter soil applications in different doses, with or without urea inhibitors, is of paramount importance for the viability and proper destination of poultry residues, minimizing $\mathrm{N}$ losses and pollution potential. In this context, the aims of the present study were to: (i) evaluate effects of the urease inhibitor NBPT on chemical soil attributes and percolate electric conductivity when added to the poultry litter, (ii) evaluate the behavior of soil chemical attributes and conductivity $(\mathrm{P}<0.05)$, and (iii) evaluate Pearson's correlations and pedotransfer functions for soil $\mathrm{pH}$, organic matter and $\mathrm{CEC}$ as a function of soil attributes.

\section{Material and Methods}

\subsection{Experimental Conditions, Soil}

This study was carried out at Rio Verde University (UniRV), Fazenda Fontes do Saber, in the municipality of Rio Verde, Goiás, Brazil, Longitude $50^{\circ} 57^{\prime} 55^{\prime \prime} \mathrm{W}$ and Latitude $17^{\circ} 47^{\prime} 03^{\prime \prime} \mathrm{S}$ at an average elevation of $787 \mathrm{~m}$. The collected soil was classified as a dystrophic Red Latossol, with a typical caulinitic-gibbsitic mineralogy (EMBRAPA, 2013), collected from a eucalyptus forest area from a depth of 0-20 cm. Soil fertility was characterized before the beginning of the experiment, following the methodologies proposed by Silva (2009).

Soil pH was determined using a potentiometer (Digimed, model DM 22, Brazil) with a combined electrode in a $0.01 \mathrm{~mol} \mathrm{~L}^{-1} \mathrm{CaCl}_{2}$ solution at a 1:2.5 soil: solution ratio, in a $100 \mathrm{~mL}$ vial stirred with a glass rod and allowed to stand for one hour. Subsequently, $5 \mathrm{~mL}$ of the SMP solution was added to the flask, which was shaken, followed by a new reading using the same potentiometer with a combined electrode to determine potential acidity $(\mathrm{H}+\mathrm{Al})$, according to Silva (2009).

Exchangeable $\mathrm{Ca}, \mathrm{Mg}$ and $\mathrm{Al}$ contents were quantified using $10 \mathrm{~cm}^{3}$ air dry fine earth (ADFE) in $180 \mathrm{~mL}$ plastic cups, with the addition of $50 \mathrm{~mL}$ of $1 \mathrm{~mol} \mathrm{~L}^{-1} \mathrm{NH}_{4} \mathrm{Cl}$, stirring for 10 minutes folowed by 16 hours at rest. Aliquots of the supernatants were then analyzed by inductively coupled plasma emission spectrometry (Perkin Elmer Optima 8300 ICP-OES). To determine sulfur contents, $10 \mathrm{~cm}^{3}$ ADFE and $25 \mathrm{~mL}$ of $1 \mathrm{~mol} \mathrm{~L}^{-1}$ ammonium acetate solution in $0.5 \mathrm{~mol} \mathrm{~L}^{-1}$ glacial acetic acid were shaken for 30 minutes at $180 \mathrm{rpm}$, filtered through a JP 42 blue filter adding $25 \mathrm{~mL}$ of the $1 \mathrm{~mol} \mathrm{~L}^{-1}$ ammonium acetate solution in $0.5 \mathrm{~mol} \mathrm{~L}^{-1}$ glacial acetic acid.

The sum of bases (SB) was calculated by the sum of $\mathrm{Ca}^{2+}, \mathrm{Mg}^{2+}$, and $\mathrm{K}^{+}$, whereas the cation exchange capacity (CEC) was calculated from the result of the SB plus the potential acidity $\left(\mathrm{Al}^{3+}\right.$ and $\left.\mathrm{H}^{+}\right)$. Subsequently, base saturation values (V\%) were obtained, by multiplying the sum of the bases by 100 and dividing the CEC. 
Available $\mathrm{P}, \mathrm{K}, \mathrm{Fe}, \mathrm{Mn}, \mathrm{Zn}$ and $\mathrm{Cu}$ contents were extracted using the Mehlich-1 solution containing $10 \mathrm{~cm}^{3}$ ADFE and $100 \mathrm{~mL}$ of the extractor in a $180 \mathrm{~mL}$ plastic cup and determined after shaking for 20 minutes at 180 rpm and 16 hours at rest (Silva, 2009). Boron (B) content was quantified using $10 \mathrm{~cm}^{3}$ ADFE and $20 \mathrm{~mL}$ of a $0.125 \%$ barium chloride solution, placed in a polypropylene bag and microwaved for 5 minutes at $700 \mathrm{~W}$, left to reach room temperature, followed by supernatant filtering. The $\mathrm{S}, \mathrm{P}, \mathrm{K}, \mathrm{Fe}, \mathrm{Mn}, \mathrm{Zn}, \mathrm{Cu}$ and $\mathrm{B}$ contents were determined by inductively coupled plasma emission (ICP-OES) spectrometry.

Organic matter content was determined using $1 \mathrm{~cm}^{3}$ ADFE and $10 \mathrm{~mL}$ of a $4 \mathrm{~mol} \mathrm{~L}^{-1}$ sodium dichromate solution and $20 \mathrm{~mol} \mathrm{~L}^{-1}$ sulfuric acid, followed by shaking at $180 \mathrm{rpm}$ for 10 minutes. After, it was left standing for one hour, $50 \mathrm{~mL}$ of distilled water was added to each sample and the solutions were allowed to stand for another 16 hours. Aliquots of the supernatants were then used to assay transmittance on a molecular absorption spectrophotometer, at $650 \mathrm{~nm}$ (U2900 model, Hitachi, Japan). Particle size analysis determined the percentage of silt and clay fractions by the densimeter method (EMBRAPA, 1997).

\subsection{Experimental Conditions, Poultry Litter}

The poultry litter (PL) came from a rearing system with eight poultry lots. The material used for filling the aviary floor was composed of rice husks. After bird removal from each batch, the poultry litter was treated with calcium oxide $\left(0.75 \mathrm{~kg} \mathrm{~m}^{-2}\right)$, moistened and covered with black tarpaulin for a 15-day fermentation. The raw material was air dried, sieved ( $2 \mathrm{~mm}$ diameter sieve) and the main consituents were determined according to Malavolta et al. (1997) (Table 1).

Table 1. Chemical attributes and particle size distribution of soil sampled at $0-20 \mathrm{~cm}$ depth at Fazenda Florestal II Rio Verde-GO compared to reference values

\begin{tabular}{|c|c|c|c|c|c|c|c|c|}
\hline & $\mathrm{pH}$ & $\mathrm{Ca}^{2+}$ & $\mathrm{Mg}^{2+}$ & $\mathrm{Al}^{3+}$ & $\mathrm{H}^{+}+\mathrm{Al}^{3+}$ & $\mathrm{K}^{+}$ & $\mathrm{P}$ & $\mathrm{S}$ \\
\hline & & \multicolumn{5}{|c|}{ - } & \multicolumn{2}{|c|}{ - } \\
\hline Soil & 6.5 & 4.09 & 1.28 & 0.06 & 1.08 & 0.062 & 28.23 & 6.8 \\
\hline \multirow[t]{3}{*}{ Ref. } & 4.9-5.5 & $2.5-3.5$ & $0.8-1.2$ & $0.2-0.5$ & n.d. & $0.13-0.20$ & $18-25$ & $15-30$ \\
\hline & $\mathrm{B}$ & $\mathrm{Fe}$ & $\mathrm{Mn}$ & $\mathrm{Zn}$ & $\mathrm{Na}$ & $\mathrm{Cu}$ & \multicolumn{2}{|l|}{ MO } \\
\hline & \multicolumn{6}{|c|}{ 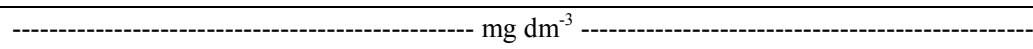 } & \multicolumn{2}{|c|}{$--\mathrm{g} \mathrm{dm}^{-3}--$} \\
\hline Soil & 0.15 & 50.92 & 39.28 & 1.14 & 3.28 & 0.04 & 21.88 & \\
\hline \multirow[t]{2}{*}{ Ref. } & $0.2-0.5$ & $15-30$ & $2.0-5.0$ & $1.1-1.6$ & n.d. & $0.4-0.8$ & \multicolumn{2}{|l|}{$20-40$} \\
\hline & SB & CEC & $\mathrm{V}$ & Sand & Clay & Silt & & \\
\hline \multicolumn{9}{|c|}{ - } \\
\hline Soil & 5.43 & 6.51 & 83 & 818.8 & 126.8 & 54.4 & & \\
\hline Ref. & n.d. & $4.3-8.6$ & $36-60$ & & & & & \\
\hline
\end{tabular}

Note. $\mathrm{pH}\left(1: 2.5 \mathrm{CaCl}_{2} 0.01 \mathrm{~mol} \mathrm{~L}^{-1}\right) ; \mathrm{Ca}, \mathrm{Mg}$ and $\mathrm{Al}$ extracted with $\mathrm{NH}_{4} \mathrm{Cl} 1 \mathrm{~mol} \mathrm{~L}^{-1} ; \mathrm{H}+\mathrm{Al}$ determined by the SMP method; $\mathrm{P}, \mathrm{K}, \mathrm{Fe}, \mathrm{Mn}, \mathrm{Zn}, \mathrm{Na}$ and $\mathrm{Cu}$ extracted with Mehlich1 solution, $\mathrm{S}$ extracted with $\mathrm{C}_{2} \mathrm{H}_{3} \mathrm{O}_{2} \mathrm{NH}_{4} 1$ mol L $\mathrm{L}^{-1}$ solution in $\mathrm{CH}_{3} \mathrm{COOH} 0.5$ mol L${ }^{-1}$, B extracted with $\mathrm{BaCl}_{2}$ a $0,125 \%$, MO extracted with $\mathrm{Na}_{2} \mathrm{Cr}_{2} \mathrm{O}_{7} 4$ mol $\mathrm{L}^{-1}$ and $\mathrm{H}_{2} \mathrm{SO}_{4} 20 \mathrm{~mol} \mathrm{~L}^{-1}, \mathrm{SB}=\mathrm{Ca}^{2+}+\mathrm{Mg}^{2+}+\mathrm{K}^{+}, \mathrm{CEC}=\mathrm{SB}+\mathrm{Al}^{3+}+\mathrm{H}^{+}, \mathrm{V} \%=((\mathrm{SB} \times 100) / \mathrm{CEC})$, Sand, clay, silt (densimeter), reference (Ref) according to Sousa and Lobato (2004).

Total nitrogen content was determined by digestion of $0.02 \mathrm{~g}$ of poultry litter in a mixture of sulfuric acid, copper sulfate, sodium sulfate and selenium followed by distillation in a Kjeldahl distillation equipment and titration with $\mathrm{NaOH}$. The extract used to quantify B was obtained by dry digestion $(0.2 \mathrm{~g}$ of poultry litter $)$ in a mortar maintained at $550^{\circ} \mathrm{C}$ for three hours and the addition of $10 \mathrm{~mL}$ of a $0.1 \mathrm{~mol} \mathrm{~L}^{-1} \mathrm{HCl}$ solution, followed by filtering and determination by inductively coupled plasma emission spectrometry (ICP-OES).

Extracts used for $\mathrm{P}, \mathrm{Ca}, \mathrm{Mg}, \mathrm{K}, \mathrm{Fe}, \mathrm{Cu}, \mathrm{Zn}$ and $\mathrm{Mn}$ determinations were obtained after nitroperchloric digestion (Malavolta et al., 1997), and determined by inductively coupled plasma emission spectrometry (ICP-OES). The electrical conductivity of the soil solution was determined using an automatic temperature compensation conductivity meter (model Tec.4MP, Tecnal). Humidity was determined by the standard oven method for 24 hours at $110^{\circ} \mathrm{C}$, according to Abreu et al. (2009).

Organic carbon content was determined according to the methodology described by Raij et al. (2001), by oxidizing $0.015 \mathrm{~g}$ poultry litter (Walkley - Black) with potassium dichromate and sulfuric acid. The digestion supernatants were titrated with a ferrous sulfate solution using diphenylalanine as indicator. 
Available macro and micronutrient contents were determined following the methodologies proposed by Silva (2009). The mineralogical composition of the poultry litter was determined by the powder method after grinding on an X-ray diffractometer (Shimadzu, model XRD-6000, Japan), using K $\alpha$-Co radiation, in step mode, from 3 to $55^{\circ} 2 \theta, 0.02^{\circ} 2 \theta ; 0.6 \mathrm{~s}$.

\subsection{First Assay: Soil Chemical Attributes Evaluation}

The experiment was conducted in a greenhouse, using $10 \mathrm{dm}^{3}$ capacity pots, filled with $9 \mathrm{~kg}$ of soil collected from a eucalyptus plantation. Eucalyptus seedlings (AEC 1528 clones originated from the hybrid Urograndis, 100 days old) were transplanted to each pot.

The experiment began on March $19^{\text {th }}, 2015$, with poultry litter application carried out on the surface of each pot, followed by the application of the NBPT (N-butyl thiophosphoric triamide) inhibitor via irrigation, at $0.063 \mathrm{~g}$ per pot, the equivalent to $14 \mathrm{~kg} \mathrm{ha}^{-1}$. Transplanting was carried out on the same day. When necessary, replanting was performed twenty days after the first transplant, replacing dead plants. The experiment was irrigated by automated spraying and divided into two irrigation treatments, at 7 and 17 hours, totaling $10 \mathrm{~mm}$ daily during the 233 experiment days.

After 233 days, the soil was collected and the chemical attributes in response to the treatments were analyzed. Sampling was carried out using a Dutch soil auger, removing the soil samples by drilling a hole in each pot and exploring the entire pot profile. Soil samples were then conditioned in plastic bags, identified, transported to the laboratory, and analyzed according to previously described methodology (Silva, 2009).

The experimental design was a completely randomized design (CRD) in a factorial scheme with an additional treatment $(2 \times 6+1)$, two types of poultry litter, with and without NBPT, and six poultry litter doses $(22.5,45$, $90,180,360$ and $720 \mathrm{~g}$ ) on a dry basis, corresponding to $5,10,20,40,80$ and $160 \mathrm{t} \mathrm{ha}^{-1}$, plus the controls (without poultry litter), in four replications, totaling 52 pots.

\subsection{Second Assay: Soil Solution and Percolate Electrical Conductivity Evaluations}

A second assay with the same treatments began on 03/31/2016, but it was conducted inside a 5-year-old eucalyptus forest. The treatments were mounted in $2 \mathrm{dm}^{3}$ PET (polyethylene terephthalate) bottles, on a support platform, 1 meter height, $5 \mathrm{~cm}$ in width and 6 meters in length (Figure 1). The pots were assembled by cutting the PET bottle in half and using only the top parts with the lids, inverted, fixed to the platform and filled with $1,000 \mathrm{~g}$ of soil and the poultry litter doses, with or without NBPT. To store the percolate, $0.5 \mathrm{dm}^{3}$ plastic bottles were attached to the lower portion of the pots (Figure 1).

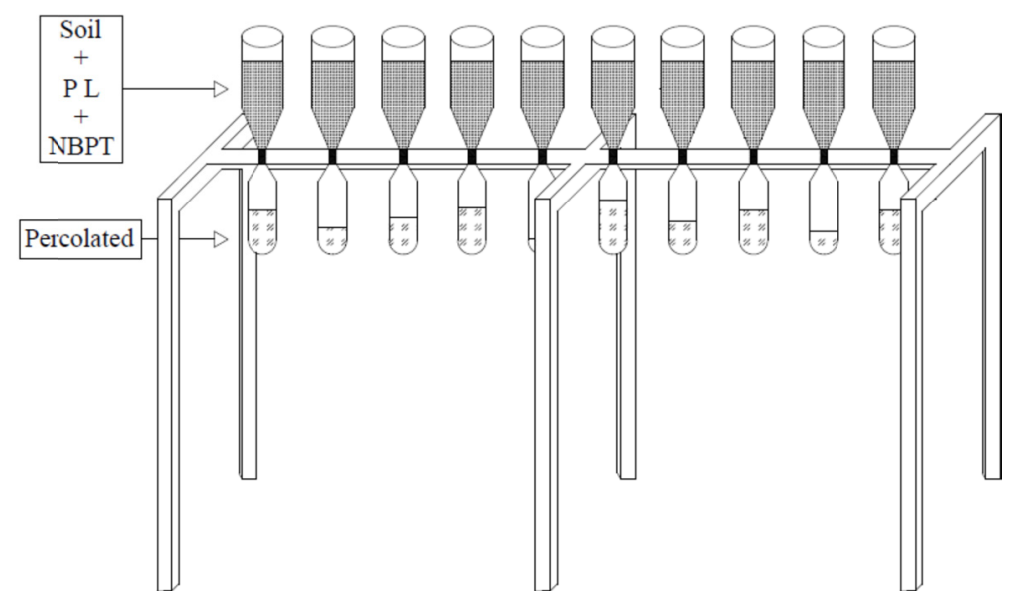

Figure 1. Illustration of $2 \mathrm{dm}^{3}$ PET pots filled with 1,000 $\mathrm{g}$ of soil plus poultry litter dose with or without NBPT and $0.5 \mathrm{dm}^{3}$ bottles for percolate collection

This experiment was conducted for four weeks. Irrigations were carried out every two days with a volume similar to that used in the greenhouse assay. The surplus water was percolated in $0.5 \mathrm{~L}$ plastic bottles and collected every seven days. After each collection, the percolates were filtered with filter paper \#42 and transferred to acrylic pots, stored in a refrigerator at $5{ }^{\circ} \mathrm{C}$. Electrical conductivity was determined in both the percolate and the soil, with a Tecnal Tec. 4MP automatic temperature compensation conductivity meter. 


\subsection{Soil Chemical Attributes Assessed in the Tests}

The soil chemical attributes evaluated in the first test were $\mathrm{pH}$, macronutrient and micronutrient contents, sum of bases, base saturation ( $\mathrm{V} \%)$, CEC and organic matter content. The soil chemical attributes evaluated in the second test was percolate electrical conductivity.

\subsection{Statistical Analysis}

The data obtained from the different attributes analyzed in both assays were submitted to an analysis of variance with regression application by orthogonal polynomials for poultry litter doses and types using Tukey's average comparison test at a 5\% probability, using the Assistat 7.7 program (Silva, 2015). Pearson's correlations coefficients and pedotransfer functions (PTF) were obtained using the Proc Cor and Proc Reg routines available in the SAS statistical program (SAS, 2001).

\section{Results and Discussion}

The analysis of the chemical attributes of the soil collected from the $0-20 \mathrm{~cm}$ layer (Table 1) before treatment exhibited values outside the range reported in the study carried out by Sousa and Lobato (2004). Soil $\mathrm{pH}$ and V\% values, $\mathrm{Ca}, \mathrm{Mg}, \mathrm{P}, \mathrm{Fe}$ and $\mathrm{Mn}$ contents were higher than the reference values, while $\mathrm{K}, \mathrm{S}, \mathrm{B}$ and $\mathrm{Cu}$ contents were lower.

Poultry litter chemical attributes (Table 2) were different from values reported in the literature. This difference depends on the number of housed batches, permanence of the animals on the litter, handling and absorbent material used at the beginning (Richart et al., 2014). Thus, poultry litter chemical attributes are very variable.

Table 1. Total chemical analysis, electrical conductivity and humidity of the poultry litter used as soil conditioner

\begin{tabular}{|c|c|c|c|c|c|c|c|c|c|c|c|c|c|c|}
\hline & $\mathrm{N}$ & $P$ & $\mathrm{~K}$ & $\mathrm{Ca}$ & $\mathrm{Mg}$ & $\mathrm{S}$ & B & $\mathrm{Cu}$ & $\mathrm{Fe}$ & $\mathrm{Mn}$ & $\mathrm{Zn}$ & $\mathrm{C}$ & $\mathrm{EC}$ & Hum \\
\hline & -- & ---- & --- & $\mathrm{kg}^{-1}$ & 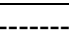 & ----- & -- & ----- & $\mathrm{g} \mathrm{kg}^{-1}$ & 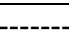 & ---- & $\mathrm{g} \mathrm{dm}^{-3}$ & $\mathrm{dS} \mathrm{m}^{-1}$ & $\%$ \\
\hline $\mathrm{Tt}$ & 26.4 & 9.18 & 48 & 15.39 & 18.6 & 3.8 & 13.3 & 890.9 & 3814 & 559 & 745 & 162.5 & 0.21 & 12 \\
\hline
\end{tabular}

Note. N: Nitrogen (digestion with $\mathrm{H}_{2} \mathrm{SO}_{4}, \mathrm{CuSO}_{4}, \mathrm{Na}_{2} \mathrm{SO}_{4}$ and Se in Kjeldahl), B: Boron (dry digestion at $550{ }^{\circ} \mathrm{C}$ ), P: Phosphorous, K: Potassium, Ca: Calcium, Mg: Magnesium, S: Sulphur, B: Boron, $\mathrm{Cu}$ : Copper, Fe: Iron, Mn: Manganese, Zn: Zinc (nitroperchloric digestion), EC: electrical conductivity (conductivity meter), C: Carbon (muffle furnace at $500{ }^{\circ} \mathrm{C}$ ), Hu: Humidity (stove at $110^{\circ} \mathrm{C}$ for 24 hours).

Nutrients contained in the poultry litter based on dry matter were $29.6 \mathrm{~g} \mathrm{~N} \mathrm{~kg}^{-1}, 26.6 \mathrm{~g} \mathrm{P} \mathrm{kg}^{-1}, 38.0 \mathrm{~g} \mathrm{~K} \mathrm{~kg}^{-1}, 47 \mathrm{~g}^{-1}$ $\mathrm{Ca} \mathrm{kg}^{-1}$ and $6.6 \mathrm{~g} \mathrm{Mg} \mathrm{kg}^{-1}$.

The X-rays diffraction analysis of the poultry litter indicated the presence of poorly crystalline organic matter and the following crystalline minerals: calcium carbonate, quartz, calcium oxide and struvite (Figure 2). Struvite $\left(\mathrm{NH}_{4} \mathrm{MgPO}_{4} \cdot 6 \mathrm{H}_{2} \mathrm{O}\right)$ is a magnesium ammonium and phosphate hexahydrate containing approximately $12 \% \mathrm{P}$ $\left(27.5 \% \mathrm{P}_{2} \mathrm{O}_{5}\right), 5.7 \% \mathrm{NH}_{4}-\mathrm{N}$ and $9.5 \% \mathrm{Mg}$ (Forrest et al., 2008). This mineral has been detected in wastewater, landfill slurry, cattle feces and even in human urine (Schuiling \& Anrade, 1999; Adnan et al., 2003). The mineralogical composition of the litter reflects the addition of calcium compounds (limestone and virgin lime) after chicken removal, to decrease the formation of smelly volatile compounds (Dai-Pra et al., 2009). The presence of struvite is the result of the continuous addition of feces and urine to semi-solid animal waste (Cassol et al., 2001). 


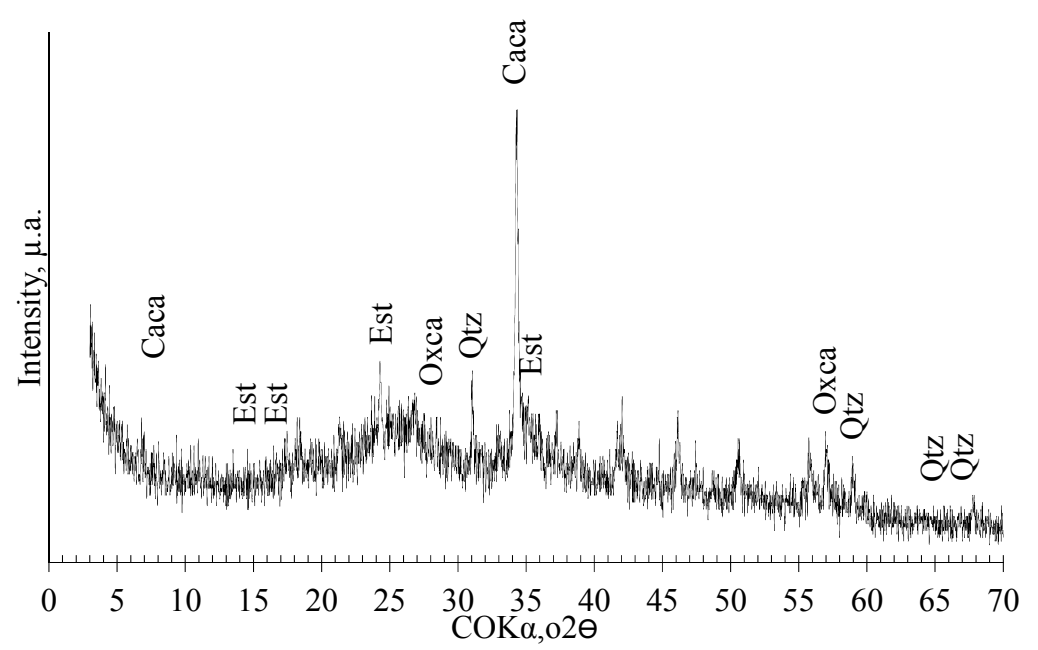

Figure 1. X-rays diffraction of the poultry litter indicating mineralogical variation; Caca: Calcium Carbonate, Qtz: Quartz, Oxca: Calcium Oxide and Est: Struvite

\subsection{Evaluation of Soil Chemical Attributes}

No statistically significant effect $(\mathrm{p}>0.05)$ was observed regarding the urease inhibitor when comparing soil chemical attributes. The applied poultry litter dose, however, led to differences between treatments for all analyzed attributes except potential acidity, which did not respond to fertilization with poultry litter. Soil $\mathrm{pH}$ values were directly influenced by the poultry litter doses, where the highest value was 7.45 at $136 \mathrm{t} \mathrm{PL} \mathrm{ha}^{-1}$ (Figure 3), with $\mathrm{pH}$ increase over $13 \%$ comparing the control and the highest tested poultry litter dose. Santos et al. (2004) and Andrade et al. (2015) observed a rise in soil pH with poultry litter applications, justified by the presence of calcium carbonate and calcium oxide (Table 2) from the poultry litter disinfection treatments carried out between bird lots. Doses higher than $20 \mathrm{t} \mathrm{PL} \mathrm{ha}^{-1}$ altered $\mathrm{pH}$ values to above the reference values for agriculture, which ranges from 5.5 to $6.3 \mathrm{t} \mathrm{PL} \mathrm{ha}^{-1}$ (Table 1). Values higher than $6.5 \mathrm{t} \mathrm{PL} \mathrm{ha}^{-1}$ can lead to decreases in micronutrient availability, like Fe, $\mathrm{Mn}, \mathrm{Cu}$ and $\mathrm{Zn}$ (Souza et al., 2007), and limit plant root growth by limiting nutrient water absorption.

Exchangeable Ca contents (Figure 3) were adjusted to a quadratic regression model, with the highest estimated dose higher than the dose tested herein. Several authors have also observed increases in the Ca content of poultry litter-fertilized soils (Blum et al., 2003; Santos et al., 2004). An 81\% increase of soil Ca contents was observed at the $160 \mathrm{t} \mathrm{PL} \mathrm{ha}^{-1}$ dose compared to the controls. Poultry litter dose above $20 \mathrm{t} \mathrm{ha}^{-1}$ led to Ca levels above the reference values (Table 1). Ca accumulation is justified by Ca poultry litter content, of $15.4 \mathrm{~g} \mathrm{~kg}^{-1}$ surpassing the $2 \mathrm{t} \mathrm{ha}^{-1}$ of Ca applied to the soil at the $160 \mathrm{tha}^{-1}$ dose (Table 3).

(a)

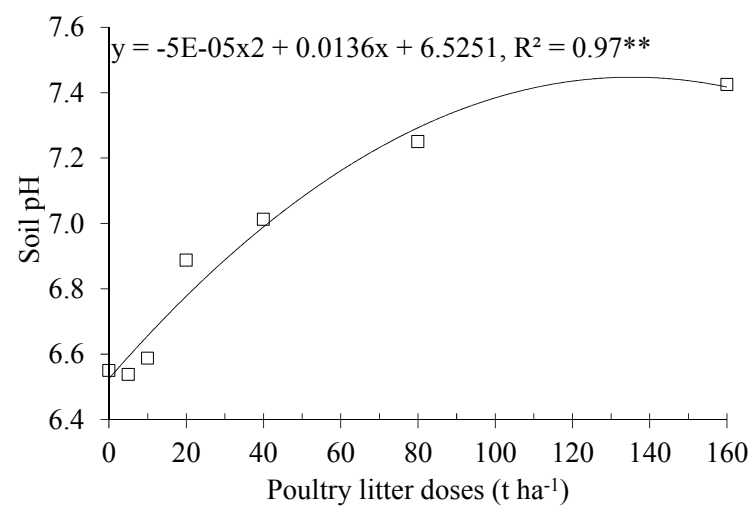

(b)

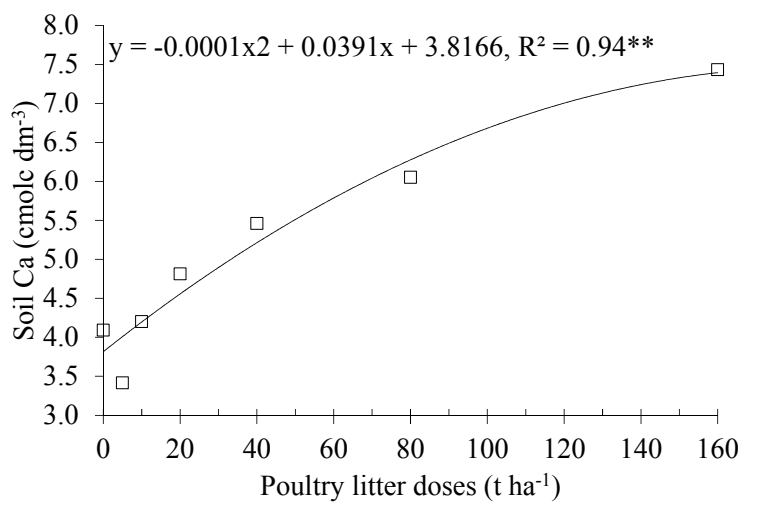

Figure 3. Polinomial regression equations for soil $\mathrm{pH}$ (a) and calcium (b) depending on the poultry litter dose. **, significant at $1 \%$ probability by the $\mathrm{F}$ test $(\mathrm{p} \leq 0.01)$ 
Mg (Figure 4a), K (Figure 4b), P (Figure 4c) and S (Figure 4d) values were adjusted to a positive linear model. Increasing soil content of these elements was observed with increasing poultry litter dose. Similar results were observed by Santos et al. (2004) for Mg, Santos et al. (2004), Carvalho et al. (2011) and Silva et al. (2012) for K and $\mathrm{P}$ and Carvalho et al. (2011) for S. The applied poultry litter increased $\mathrm{Mg}, \mathrm{K}, \mathrm{P}$ and $\mathrm{S}$ contents by 257,77 , 1,795 and $341 \%$, respectively. Doses above $20 \mathrm{t} \mathrm{ha}^{-1}$ of poultry litter increased $\mathrm{Mg}$ and $\mathrm{P}$ contents to above reference levels (Sousa \& Lobato, 2004), while the same was not observed for K and S (Table 1).

(a)

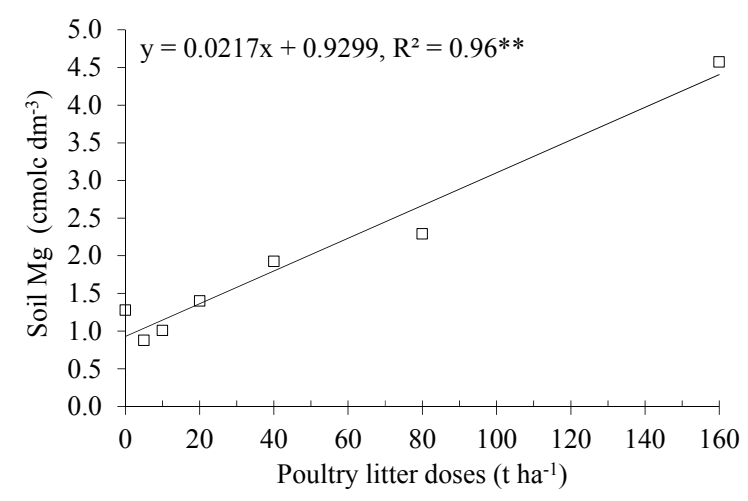

(c)

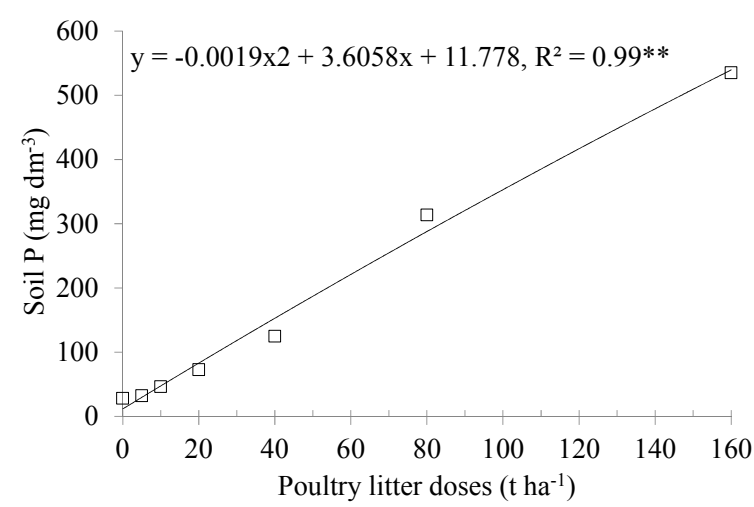

(b)

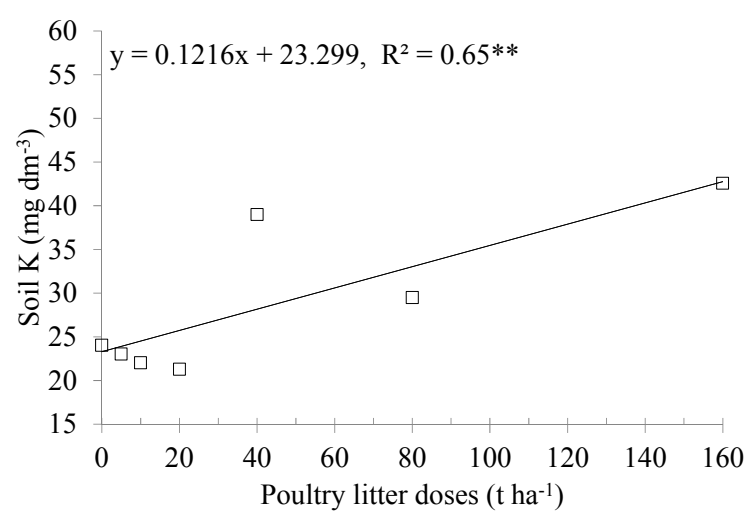

(d)

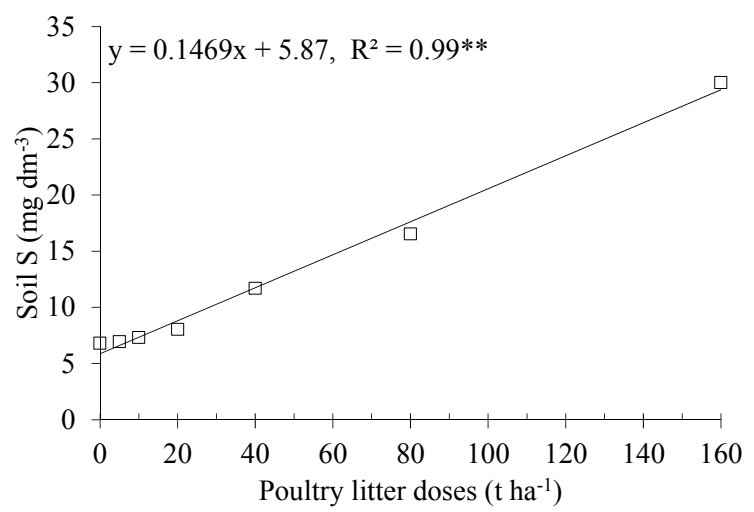

Figure 4. Linear regression equations for magnesium (a); potassium (b); phosphorus (c) and sulfur (d) soil contents as a function of poultry litter doses. ${ }^{* *}$ significant at $1 \%$ probability by the $\mathrm{F}$ test $(\mathrm{p} \leq 0.01)$

Poultry litter added $\mathrm{K}>\mathrm{Mg}>\mathrm{P}>\mathrm{S}$ to the soil, in decreasing order (Table 3). $\mathrm{K}$ displayed the lowest soil availability, even with the highest content percentage in the poultry litter. The opposite was observed for P, which, although comprising a lower percentage of the poultry litter, showed a 23 -fold increased availability compared to K. Potassium displays high leaching capacity, mainly in sandy soils (Neves et al., 2009). Therefore, the use of poultry litter at higher than $20 \mathrm{t} \mathrm{ha}^{-1}$ doses can lead to environmental contamination, either by $\mathrm{K}$ leaching or by raising soil P and Mg. Beavers et al. (2010), reported that P levels increased significantly after 3 years of poultry litter application in soils. 
Table 3. Total chemical contents of nutrients applied to the soil by poultry litter at 5, 10, 20, 40, 80 and $160 \mathrm{tha}^{-1}$ doses

\begin{tabular}{|c|c|c|c|c|c|c|c|c|c|c|c|c|}
\hline Doses & $\mathbf{N}$ & $\mathbf{P}$ & $\mathbf{K}$ & $\mathbf{C a}$ & Mg & $\mathbf{S}$ & $\mathbf{F e}$ & B & $\mathrm{Cu}$ & Mn & $\mathbf{Z n}$ & $\mathbf{N a}$ \\
\hline --- t ha ${ }^{-1}$--- & --------- & ---------- & --------. & 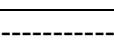 & 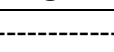 & $\mathrm{g} \mathrm{ha}^{-1}$ & 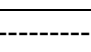 & 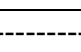 & 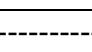 & - & 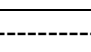 & \\
\hline 5 & 132.0 & 45.9 & 242.4 & 77.0 & 92.8 & 19.0 & 19.1 & 0.07 & 4.5 & 2.8 & 3.7 & 7.0 \\
\hline 10 & 264.0 & 91.8 & 484.8 & 153.9 & 185.6 & 38.0 & 38.1 & 0.13 & 8.9 & 5.6 & 7.5 & 14.1 \\
\hline 20 & 528.0 & 183.6 & 969.6 & 307.8 & 371.2 & 76.0 & 76.3 & 0.27 & 17.8 & 11.2 & 14.9 & 28.1 \\
\hline 40 & $1,056.0$ & 367.2 & $1,939.2$ & 615.6 & 742.4 & 152.0 & 152.6 & 0.53 & 35.6 & 22.4 & 29.8 & 56.2 \\
\hline 80 & $2,112.0$ & 734.4 & $3,878.4$ & $1,231.2$ & $1,484.8$ & 304.0 & 305.1 & 1.06 & 71.3 & 44.7 & 59.6 & 112.5 \\
\hline 160 & $4,224.0$ & $1,468.8$ & $7,756.8$ & $2,462.4$ & $2,969.6$ & 608.0 & 610.3 & 2.13 & 142.5 & 89.4 & 119.2 & 225.0 \\
\hline
\end{tabular}

Note. Values were calculated from the chemical composition of the poultry litter (Table 2), as total content, except for sodium, calculated as available content.

Soil organic matter content increased linearly and positively with increasing poultry litter doses (Figure 5). A $47 \%$ increase in OM content was observed at the $160 \mathrm{t} \mathrm{ha}^{-1}$ dose compared to the controls, albeit within the reference range (Table 1). Similar results were reported by Lima et al. (2007), Silva et al. (2012) and Andrade et al. (2015) when using poultry litter as an organic fertilizer. This indicates improvement of soil quality, since loam texture soils such as the one evaluated herein display increased water retention, due to organic matter increases, in addition to increasing nutrient availability to plant root systems (Kiehl, 1997). B displayed a distinct behavior compared to the other nutrients, since this element was adjusted to a quadratic model, with minimum efficiency calculated as $58 \mathrm{tPL} \mathrm{ha}^{-1}$ (Figure $5 \mathrm{~b}$ ).

(a)

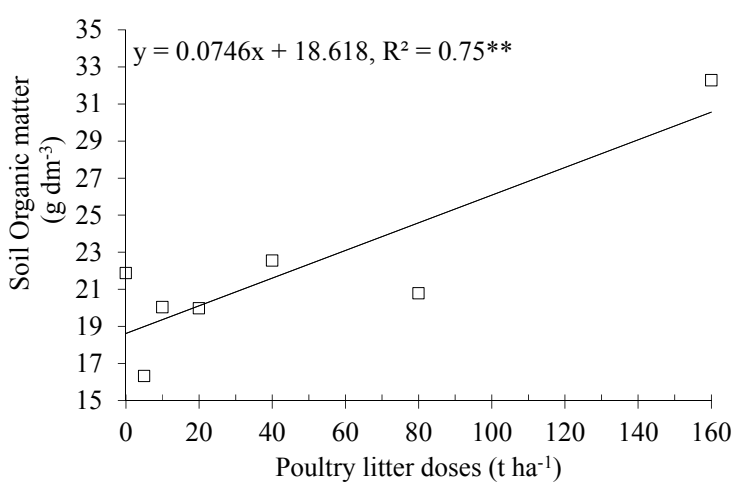

(b)

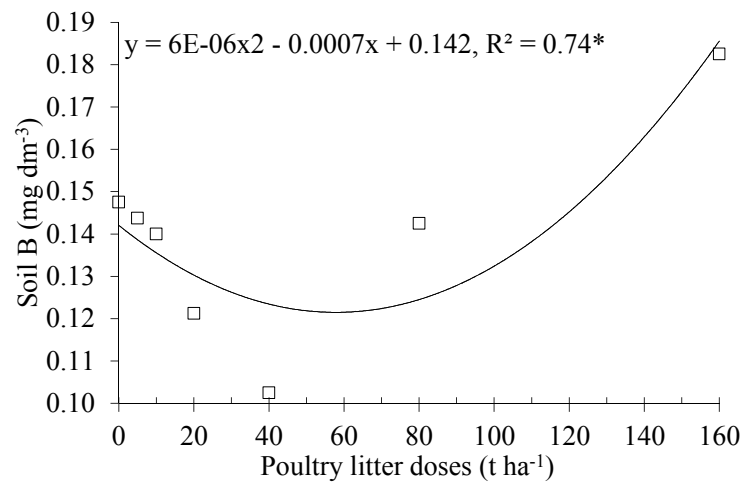

Figure 5. Linear and polynomial regression equations for soil organic matter (a) and B (b) contens, respectively, as a function of poultry litter doses. **, * significant at $1 \%$ and $5 \%$ probabilities, respectively, by the $\mathrm{F}$ test. $\mathrm{p} \leq$ 0.01 and $\mathrm{p} \leq 0.05$, respectively.

The available B soil content at $40 \mathrm{tha}^{-1}$ poultry litter dose was lower than the values reported by Sousa and Lobato (2004). It is important to note that B deficiency may compromise meristematic plant tissues by inhibiting growth and affecting normal plant development (Marschner, 1995).

The main B deficiency symptom in eucalyptus culture is apical death, first documented by Vail et al. (1957) and Savory (1962). The explanation for the behavior of the available B soil content with increasing poultry litter doses is mainly related to soil $\mathrm{pH}$, since soils with neutral or close to neutral $\mathrm{pH}$ promote greater $\mathrm{B}$ adsorption on colloid surfaces, leading to low availability in the soil solution, while the opposite is observed when the soil $\mathrm{pH}$ is altered to lower or higher values, reducing adsorption and increasing availability (Silveira et al., 2007; Soares et al., 2008).

Fe contents were adjusted to a negative linear regression model (Figure 6). Increasing doses of poultry litter led to decreasing $\mathrm{Fe}$ availability, to $48 \%$ at the $160 \mathrm{t} \mathrm{PL} \mathrm{ha}^{-1}$ dose compared to the controls, even when applying 0.61 $\mathrm{t} \mathrm{ha} \mathrm{a}^{-1}$ of the residue. The control soil displayed available Fe content above the reference values indicated by Sousa and Lobato (2004). 


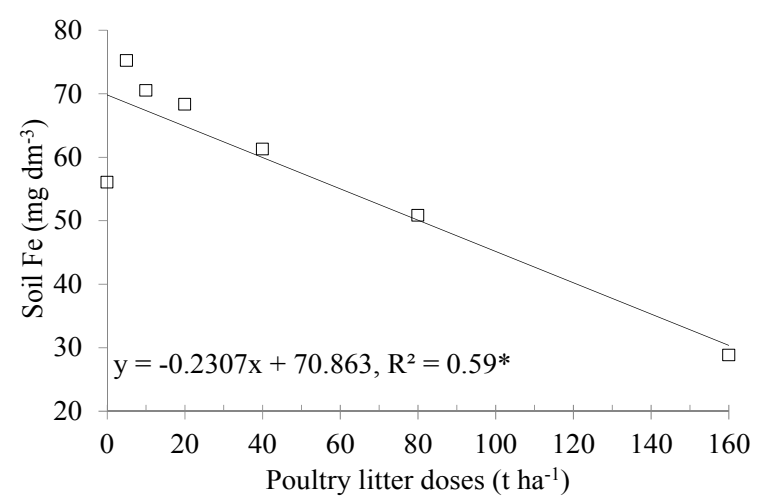

Figure 6. Linear regression equation for soil iron, as a function of poultry litter doses. *, significant at $5 \%$ probability by the $\mathrm{F}$ test $(\mathrm{p} \leq 0.05)$

The $160 \mathrm{tha}^{-1}$ poultry litter dose led to soil Fe content close to the reference values. The decrease in available Fe content is linked to $\mathrm{pH}$ increases. Malavolta (1979) states that, Fe availability is reduced as soil $\mathrm{pH}$ increases, due to the complexation of the available Fe by organic matter (Zanão-Júnior et al., 2007; Cunha et al., 2011) and iron oxidation $\left(\mathrm{Fe}^{2+}\right)$, forming low solubility iron oxides (Gonçalves et al., 2011) (Costa \& Bigham, 2009).

$\mathrm{Mn}$ (Figure 7a), Zn (Figure 7b), Na (Figure 7c) and $\mathrm{Cu}$ (Figure 7d) values were adjusted to a positive linear regression model, increasing their availability with increasing amounts of poultry litter. Comparing the available content of these elements in the control treatment to the soil that received $160 \mathrm{tha}^{-1}$ of poultry litter, an increase in availability was observed, of $98 ; 6,537 ; 639 ; 45,726 \%$ for $\mathrm{Mn}, \mathrm{Zn}, \mathrm{Na}$ and $\mathrm{Cu}$, respectively (Figure 7).

(a)

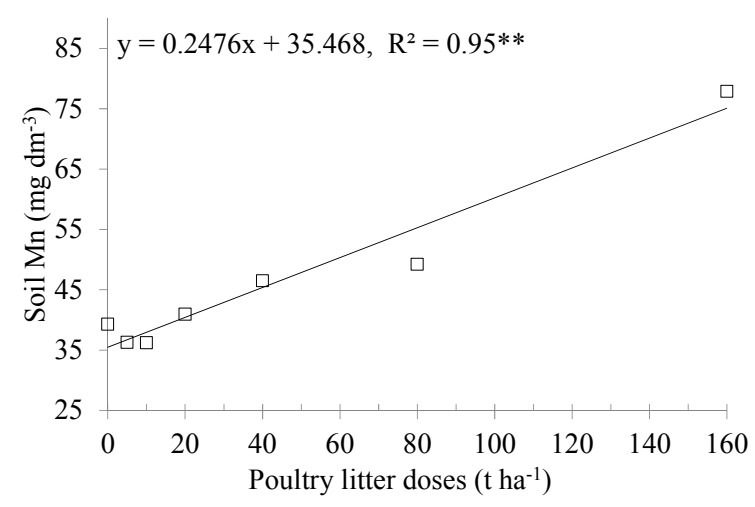

(c)

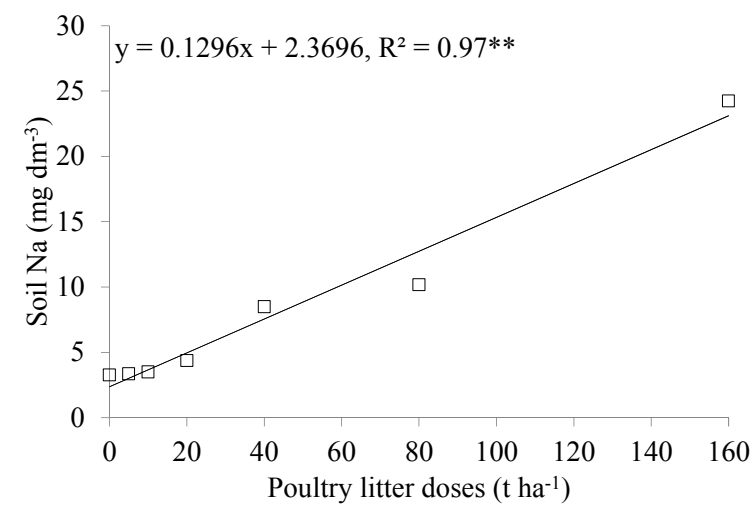

(b)

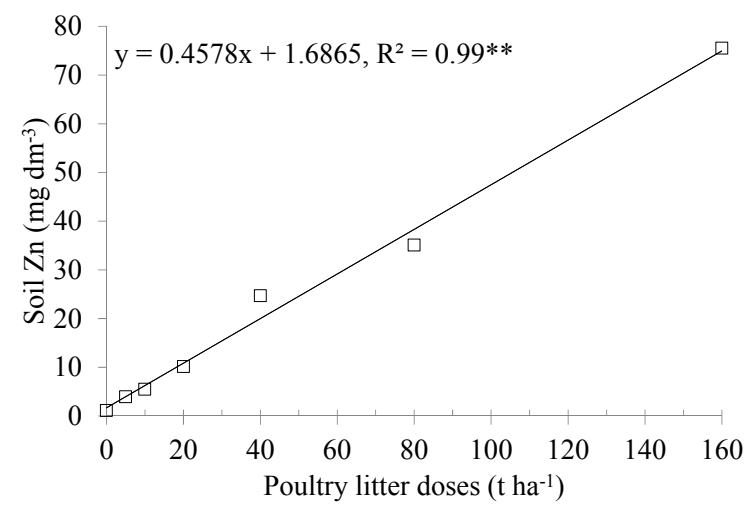

(d)

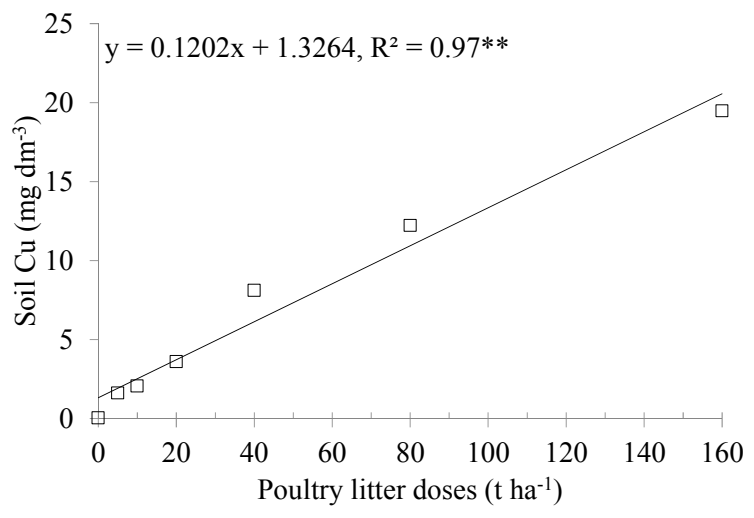

Figure 7. Linear regression equations for manganese (a); zinc (b); sodium (c) and copper (d) as a function of poultry litter doses. $* *$, significant at $1 \%$ probability by the $\mathrm{F}$ test. $(\mathrm{p} \leq 0.01)$ 
Santos et al. (2004) and Nachtigall et al. (2009) reported similar results, while Malavolta (1979) proposed the opposite, that $\mathrm{pH}$ increases in fact decrease $\mathrm{Mn}, \mathrm{Zn}$ and $\mathrm{Cu}$ availability. The rationale for the results observed herein is that the poultry litter contained 559, 745 and $890 \mathrm{mg} \mathrm{kg}^{-1}$ of $\mathrm{Mn}, \mathrm{Zn}$ and $\mathrm{Cu}$, respectively (Table 1); thus increases in $\mathrm{pH}$ reduced the availability of these elements, while application of high doses suppressed $\mathrm{pH}$ effects and increased $\mathrm{Mn}, \mathrm{Zn}$ and $\mathrm{Cu}$ availability.

The available $\mathrm{Mn}, \mathrm{Zn}, \mathrm{Na}$ and $\mathrm{Cu}$ levels in poultry litter treated soils were higher than the reference values indicated by Sousa and Lobato (2004). High levels of these elements can promote phytotoxicity through competition, especially in places presenting iron deficiency (Soares et al., 2000). Soil contamination can, thus, occur by the use of agricultural residues such as poultry litter, which is usually not applied $>40 \mathrm{tPL} \mathrm{ha}{ }^{-1}$, but is applied succesively, over time, raising elemental levels to toxic intensities.

$\mathrm{Cu}$ levels in the soil were adjusted to a positive linear regression model, increasing with increasing poultry litter doses, reaching $45.726 \%$, at the highest dose of $160 \mathrm{t} \mathrm{PL} \mathrm{ha}^{-1}$ compared to the control treatment (Figure 7d), displaying soil contamination ability. Soil cation exchange capacity (CEC) (Figure 8a), base saturation (BS) (Figure 8b), V\% and electrical conductivity - EC (Figure 8c) were adjusted to a positive linear regression model. When comparing the control treatment with the $160 \mathrm{t} \mathrm{PL} \mathrm{ha}^{-1}$ dose, 97, 14 and $1.309 \%$ increases were observed for CTC, BS and CE, respectively.

CEC is defined by Ronquim (2010) as the total amount of cations retained on the surface of these materials in exchangeable condition $\left(\mathrm{Ca}^{2+}+\mathrm{Mg}^{2+}+\mathrm{K}^{+}+\mathrm{H}^{+}+\mathrm{Al}^{3+}\right)$. Values considered adequate by Sousa and Lobato (2004) range between 4 and $8.5 \mathrm{cmol}_{\mathrm{c}} \mathrm{dm}^{-3}$, thus indicating that 80 and $160 \mathrm{t} \mathrm{ha}^{-1}$ poultry litter doses raise CEC values above the reference values (Table 1). This increase is in agreement with Silva and Mendonça (2007) as a function of soil $\mathrm{pH}$ and $\mathrm{OM}$ content increase, provided by the poultry litter.

The results demonstrate the active participation of $\mathrm{pH}$ and $\mathrm{OM}$ in soil CEC, since $\mathrm{pH}, \mathrm{CEC}$ and $\mathrm{OM}$ values increase with increasing poultry litter levels. The opposite was observed for Fe content, where availability decreased with increasing poultry litter applications. Base saturation $(\mathrm{V} \%)$ is considered a soil quality indicator, and, according to Ronquim (2010), soils are considered fertile when V\% values are higher than $50 \%$. Sousa and Lobato (2004) apply values ranging from 36 to $60 \%$. Thus, V\% values determined herein are higher than those adopted by Sousa and Lobato (2004) as ideal. 
(a)

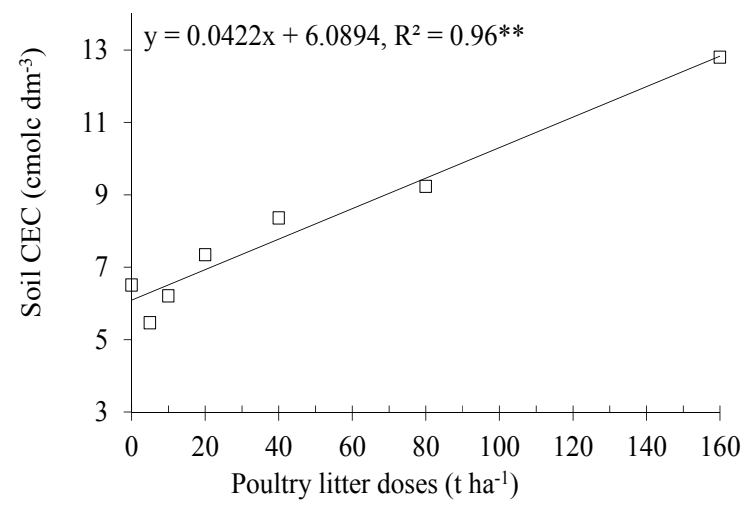

(b)

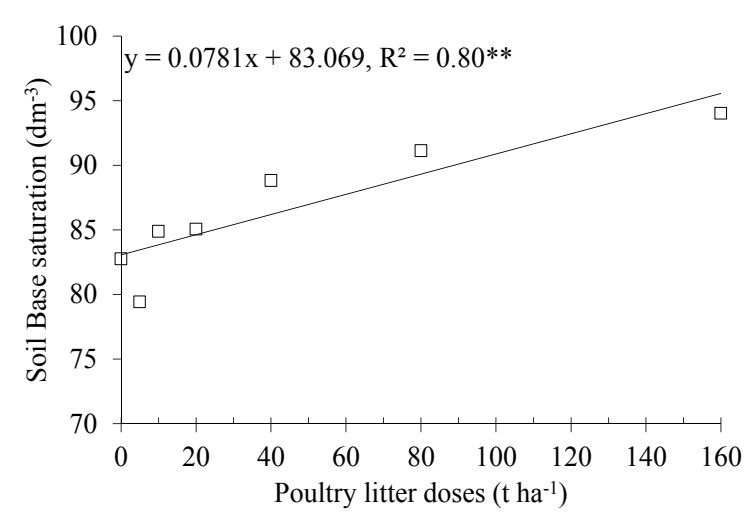

(c)

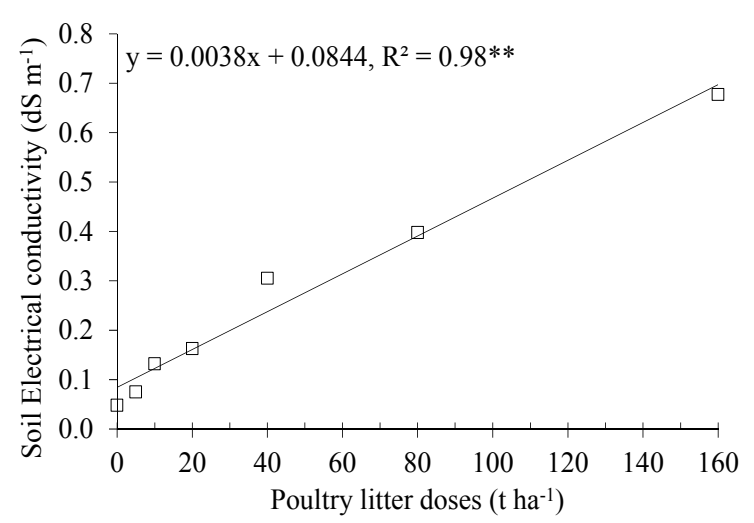

Figure 8. Linear regression equations for soil CEC (a), soil base saturation (b) and electrical conductivity (c), as a function of poultry litter doses. ${ }^{* *}$, significant at $1 \%$ probability by the $\mathrm{F}$ test $(\mathrm{p} \leq 0.01)$

V\% values above 70\% may inhibit plant development. Bernadino et al. (2007) and Possamai et al. (2014) demonstrated increases plant quality with increasing base saturation (V\%) up to $70 \%$, and inhibition above this percentage. Most of the time, to raise $\mathrm{V} \%$, soil conditioners containing high $\mathrm{Ca}$ and $\mathrm{Mg}$ levels in high doses are usually applied, which can inhibit K uptake by plants (Andreotti et al., 2000).

Soil electrical conductivity, despite having increased more than $1,300 \%$ at the $160 \mathrm{t} \mathrm{PL} \mathrm{ha}^{-1}$ dose in relation to the control treatment (Figure 8c), did not reach the value considered limiting by Dias and Blanco (2010), of 4.0 $\mathrm{dS} \mathrm{m} \mathrm{m}^{-1}$, when analysing over 60 different cultures. Ghini et al. (2002) also observed an increase in soil EC with poultry litter applications, due to the composition of this residue (Table 2), which contains considerable amounts of salts that increase soil EC values.

\subsection{Soil and Percolate Electrical Conductivity Evaluation}

The electric conductivity of the percolate was influenced by the poultry litter doses and the sampling time, increasing with increasing residue doses and decreasing with increasing sample time (Figure 9). The 160 t PL $\mathrm{ha}^{-1}$ dose increased percolate EC by more than $2,000 \%$ when compared to the control treatment, reaching over $7.04 \mathrm{dS} \mathrm{m}^{-1}$ at 7 days, exceeding the upper limit critical value of $4.0 \mathrm{dS} \mathrm{m}^{-1}$ for the survival of most agricultural crops (Freire and Freire, 2007; Silva et al., 2008). 


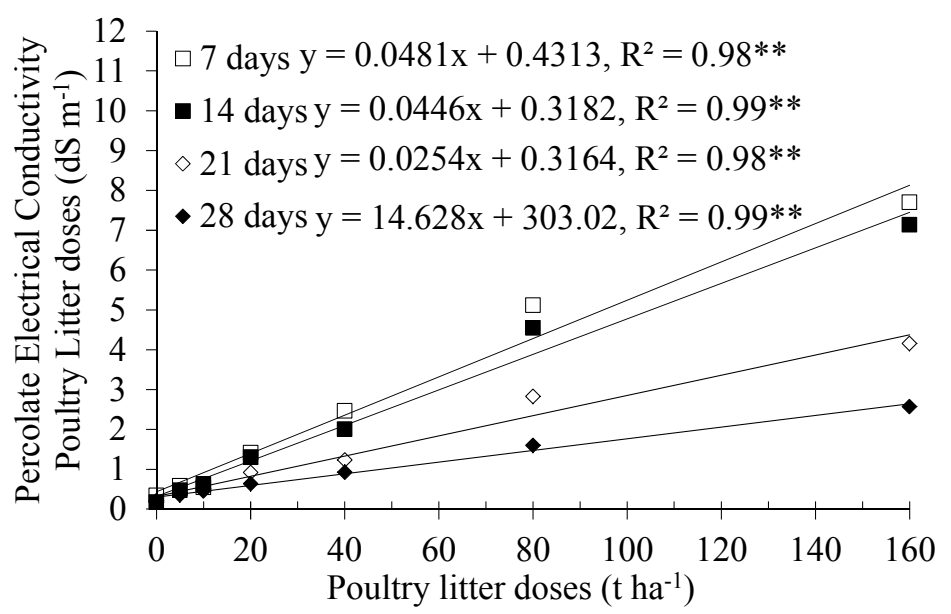

Figure 9. Linear regression equations for the electric conductivity of the soil percolate at 7, 14, 21 and 28 days as a function of poultry litter doses. ${ }^{* *}$ significant at $1 \%$ probability by the $\mathrm{F}$ test $(\mathrm{p} \leq 0.01)$

Percolate EC values declined approximately $50 \%$ after 28 days when compared to EC values at 7 days. Calculations using the EC percolate values observed in the $160 \mathrm{tha}^{-1}$ treatment indicate that, for each ton of poultry litter added to the soil, EC increases in $0.046,0.044,0.025$ and $0.015 \mathrm{dS} \mathrm{m}^{-1}$ at $7,14,21$ and 28 days, respectively.

These results confirm that the 80 and $160 \mathrm{t} \mathrm{ha}^{-1}$ doses of poultry litter under the evaluated conditions increased salt levels in the soil solution, damaging plant metabolism. Magalhães (2016) observed eucalyptus seedling deaths when irrigating the plants with wastewater at an EC of $3.7 \mathrm{dS} \mathrm{m}^{-1}$. The decrease observed in the percolate EC values is related to leaching losses (Neves et al., 2009; Pessoa et al., 2010), causing soil alterations due to poultry litter application, mainly at 80 and $160 \mathrm{t} \mathrm{PL} \mathrm{ha}^{-1}$, leading to possible compromises in soil and ground water quality.

3.3 Pearson's Correlations Coefficients and Pedotransfer Functions for PH, Organic Matter and CEC as a Function of Soil Chemical Attributes

The $\mathrm{pH}, \mathrm{BS}, \mathrm{EC}, \mathrm{CEC}$ and potential acidity values, as well as $\mathrm{Fe}, \mathrm{Ca}$ and $\mathrm{Mg}$ contents observed in the present study are at the same order of magnitude as those reported by Silva et al. (2006), Netto et al. (2007), Bebé et al. (2009), and Serrano et al. (2010), respectively. In contrast to what was proposed by Malavolta (1979), Zn, Cu and $\mathrm{S}$ contents were positively correlated to $\mathrm{pH}$ values, due to the influence of $\mathrm{pH}$ on solubility processes, precipitation reactions and complexation, increasing the availability of these elements in the soil solution (Table 4). Soil $\mathrm{pH}$ values presented positive correlations to $\mathrm{Ca}, \mathrm{Mg}, \mathrm{S}, \mathrm{Zn}, \mathrm{Cu}, \mathrm{CEC}$, sum of bases and EC levels over $60 \%$ and negative correlations to potential acidity and available Fe soil content (Table 4). 
Table 4. Pearson's correlation coefficients (r) between soil chemical attributes , organic matter (OM) content and cation exchange capacity (CEC) levels

\begin{tabular}{llll}
\hline Chemical attributes & $\mathrm{pH}$ & $\mathrm{OM}$ & $\mathrm{CEC}$ \\
\hline $\mathrm{pH}$ & 1.00 & $0.36^{* *}$ & $0.62^{* *}$ \\
$\mathrm{Ca}$ & $0.63^{* *}$ & $0.58^{* *}$ & $0.92^{* *}$ \\
$\mathrm{Mg}$ & $0.60^{* *}$ & $0.73^{* *}$ & $0.86^{* *}$ \\
$\mathrm{AcPT}$ & $-0.67^{* *}$ & - & - \\
$\mathrm{K}$ & - & $0.60^{* *}$ & $0.41^{* *}$ \\
$\mathrm{P}$ & $0.59^{* *}$ & $0.61^{* *}$ & $0.86^{* *}$ \\
$\mathrm{~S}$ & $0.68^{* *}$ & $0.66^{* *}$ & $0.89^{* *}$ \\
$\mathrm{OM}$ & $0.36^{* *}$ & 1.00 & $0.71^{* *}$ \\
$\mathrm{~B}$ & - & - & - \\
$\mathrm{Fe}$ & $-0.40^{* *}$ & $-0.72^{* *}$ & $-0.71^{* *}$ \\
$\mathrm{Mn}$ & $0.45^{* *}$ & $0.88^{* *}$ & $0.62^{* *}$ \\
$\mathrm{Zn}$ & $0.61^{* *}$ & $0.72^{* *}$ & $0.73^{* *}$ \\
$\mathrm{Cu}$ & $0.67^{* *}$ & $0.42^{* *}$ & $0.63^{* *}$ \\
$\mathrm{CEC}$ & $0.62^{* *}$ & $0.71^{* *}$ & 1.00 \\
$\mathrm{SB}$ & $0.84^{* *}$ & $0.49^{* *}$ & $0.63^{* *}$ \\
$\mathrm{CE}$ & $0.71^{* *}$ & $0.54 * *$ & $0.78^{* *}$
\end{tabular}

Note. $\mathrm{pH}$ : hydrogenation potential; Ca: Calcium; Mg: Magnesium; AcPT: potential acidity; K: Potassium, P: Phosphorus; S: Sulfur; OM: organic matter; B: Boron; Fe: Iron; Mn: Manganese; Zn: Zinc; Cu: Copper; CEC: cation exchange capacity; SB: sum of bases; EC: soil electrical conductivity; -: non-significant; *: significant at a $5 \%$ probability level and **: significant at a $1 \%$ probability level.

The correlation analysis indicate that only $\mathrm{Cu}$ contributed positively $(+)$ in the selection of significant attributes $(\mathrm{p}<0.05)$ for the pedotransfer function models $(\mathrm{PTF})$, (Table 5) with a linear effect for $\mathrm{pH}(\mathrm{r}=0.85, \mathrm{p}<0.01)$.

Table 5. Pedotransfer functions (PTF) for hydrogenation potential $(\mathrm{pH})$, organic matter $(\mathrm{OM})$ and cation exchange capacity (CEC) using soil chemical attributes

\begin{tabular}{ll}
\hline Variable & \multicolumn{1}{c}{ PTF } \\
\hline $\mathrm{pH}=6.57339+0.04802 \times \mathrm{Cu}$ & $0.85^{* *}$ \\
$\mathrm{MO}=10.021+0.554 \times \mathrm{S}-0.070 \times \mathrm{Fe}+0.1443 \times \mathrm{Mn}+1.124 \times \mathrm{CEC}-0.004 \times \mathrm{CE} 21$ & $0.99^{* *}$ \\
$\mathrm{CEC}=8.016-0.027 \times \mathrm{Fe}+0.076 \times \mathrm{Zn}$ & $0.98^{* *}$ \\
\hline
\end{tabular}

Note. Cu: Copper; S: Sulfur; Fe: Iron; Mn: Mangânes; CEC: cation exchange capacity; CE21: percolate electrical conductivity at 21 days; Zn: Zinc; R2 coefficient of determination; ** significant at $1 \%$ probability.

Organic matter (OM) content correlated to 14 of the 16 evaluated soil attributes. Of these 14 attributes, 7 displayed a Pearson's linear correlation coefficient $r>0.6(\mathrm{p}<0.01)$, with positive (+) for $\mathrm{Mg}, \mathrm{K}, \mathrm{P}, \mathrm{S}, \mathrm{Mn}, \mathrm{Na}$ and CEC values and negative (-) for Fe (Table 1.4). These results are similar to those published by Garay et al. (2003) for Mg, K, P and CEC and Teixeira et al. (2003) for Mn and Fe.

The high correlation indexes between $\mathrm{OM}$ and other soil attributes confirms the importance of this parameter regarding soil quality, also confirming the quality of the poultry litter as a soil conditioner. When submitted to the Stepwise procedure, the significant attributes for the PTF were S, Mn and CEC, contributing positively (+), while Fe content and percolate EC at 21 days contributed negatively (-) (Table 5), with a linear effect for OM ( $\mathrm{R}^{2}$ $=0.99, \mathrm{p}<0.01)$.

Pearson's correlation coefficients for CEC indicate positive $(+)$ and significant correlations $(r>0 ; p<0.05)$ to the following chemical attributes: $\mathrm{pH}, \mathrm{Ca}, \mathrm{Mg}, \mathrm{P}, \mathrm{S}, \mathrm{OM}, \mathrm{Mn}, \mathrm{Zn}, \mathrm{Na}, \mathrm{Cu}, \mathrm{SB}$ and EC, and negative (-) correlations to Fe content values, with $r>0.6$ (Table 1.4). These results are similar to those reported by Garay et 
al. (2003) and Oliveira et al. (2002) for $r>0$ correlations and Gonçalves et al. (2011) and Cunha et al. (2011) for $\mathrm{r}<0$ correlations.

\section{Conclusions}

Poultry litter doses altered soil chemical attributes, except for potential acidity. Soil pH, CEC, SB and EC chemical attributes and $\mathrm{Ca}, \mathrm{Mg}, \mathrm{K}, \mathrm{P}, \mathrm{S}, \mathrm{OM}, \mathrm{Mn}, \mathrm{Zn}$ and $\mathrm{Cu}$ contents increased with increasing poultry litter doses, while soil Fe and B had an opposite trend. Over $40 \mathrm{t} \mathrm{ha}^{-1}$ dose, poultry litter negatively influenced soil sustainability, mainly due to the increasing salinity and alkalinity associated to salt content and to $\mathrm{pH}$ increases, respectively. It is important to emphasize that the poultry litter should be applied in doses smaller than $40 \mathrm{tha}^{-1}$ with chemical fertilizer complementation, and that soil monitoring should be carried out, in order to avoid saturation by the continuous application of this residues. The NBPT urease inhibitor showed no influence on soil chemical attributes.

\section{Acknowledgements}

The authors are grateful to the Coordination of Improvement of Higher Level Personnel (CAPES), Rio Verde University (Universidade de Rio Verde (UniRV)), State University of Maringá (Universidade Estadual de Maringá (UEM)), Agroindustrial Cooperative of Rural Producers of Southwest Goiania (Cooperativa Agroindustrial dos Produtores Rurais do Sudoeste Goiano (COMIGO)) and Pig and Poultry Cooperative of farmers of Goiás (Cooperativa de Suinocultores e Avicultores de Goiás (COOPERSAG)).

\section{References}

Abreu, M. F. de, Abreu, Jr. C. H., Silva, F. C., Santos, G. C. G., Andrade, J. C., Gomes, T. F., ... Andrade, C. A. de. (2009). Análises químicas de fertilizantes orgânicos (urbanos). In F. C. Silva (Ed.), Manual de análises químicas de solos, plantas e fertilizantes (pp. 398-485). Embrapa Informação Tecnológica.

Adnan, A., Mavinic, D. S., \& Koch, F. A. (2003). Pilot-scale study of phosphorus recovery through struvite crystallization-Examining the process feasibility. Journal of Environmental Engineering and Science, 2, 315-324. https://doi.org/10.1139/s03-040

Andrade, C. A. de, Bibar, P. S., Coscione, A. R., Pires, A. M. M., \& Soares, A. G. (2015). Mineralização e efeitos de biocarvão de cama de frango sobre a capacidade de troca catiônica do solo. Pesquisa Agropecuária Brasileira, 50, 407-416. https://doi.org/10.1590/S0100-204X2015000500008

Andreotti, M., Souza, E. C. A. de, Crusciol, C. A. C., Rodrigues, J. D., \& Büll, L. T. (2000). Produção de matéria seca e absorção de nutrientes pelo milho em razão da saturação por bases e da adubação potássica. Pesquisa Agropecuária Brasileira, 35, 2437-2446. https://doi.org/10.1590/S0100-204X2000001200015

Arthur, E., Tuller, M., Moldrup, P., \& De Jorge, L. W. (2015). Effects of biochar and manure amendments on water vapor sorption in a sandy loam soil. Geoderma, 243-244, 175-182. https://doi.org/10.1016/j.geoder ma.2015.01.001

Beavers, B. W., Liu, Z., Cox, M. S., Kingery, W. L., Brink, G. E., Gerard, P. D., \& McGregor, K. C. (2010). Phosphorus Dynamics in Two Poultry-Litter Amended Soils of Mississippi Under Three Management Systems. Pedosphere, 20, 217-228. https://doi.org/10.1016/S1002-0160(10)60009-4

Bebé, F. V., Rolim, M. M., Pedrosa, E. M. R., Silva, G. B., \& Oliveira, V. S. (2009). Avaliação de solos sob diferentes períodos de aplicação com vinhaça. Revista Brasileira de Engenharia Agrícola e Ambiental, 13, 781-787. https://doi.org/10.1590/S1415-43662009000600017

Bernardino, D. C. S., Paiva, H. N., Neves, J. C. L., Gomes, J. M., \& Marques, V. B. (2007). Influência da saturação por bases e da relação $\mathrm{Ca}: \mathrm{Mg}$ do substrato sobre o crescimento inicial de jacarandá-da-bahia (Dalbergia nigra (Vell.) Fr. All. ex Benth.). Revista Árvore, 31, 567-73. https://doi.org/10.1590/ S0100-67622007000400001

Bissani, C. A., Camargo, F. A. O., Gianello, C., \& Tedesco, M. J. (2004). Fertilidade dos solos e manejo da adubação. Porto Alegre: Gênesis.

Blum, L. E. B., Amarante, C. V. T., Güttler, G., Macedo, A. F., Kothe, D., Simmler, A., ... Guimarães, L. (2003). Produção de moranga e pepino em solo com incorporação de cama aviária e casca de pinus. Horticultura Brasileira, 21, 627-631. https://doi.org/10.1590/S0102-05362003000400010

Buijsman, E., Maas, H. F. M., \& Ashman, W. A. H. (1987). Anthropogenic $\mathrm{NH}_{3}$ emissions in Europe. Atmospheric Environment, 21, 1009-1022. https://doi.org/10.1016/0004-6981(87)90230-7 
Cameron, K. C., Di, H. J., \& Moir, J. L. (2013). Nitrogen losses from the soil/plant system: A review. Annals of Applied Biology, 162, 145-173. https://doi.org/10.1111/aab.12014

Carvalho, E. R., Rezende, P. M. de, Andrade, M. J. B. de, Passos, A. M. A. dos, \& Oliveira, J. A. (2011). Fertilizante mineral e resíduo orgânico sobre características agronômicas da soja e nutrientes no solo. Revista Ciência Agronômica, 42, 930-939. https://doi.org/10.1590/S1806-66902011000400015

Cassol, P. C., Gianello, C., \& Costa, V. E. U. (2001). Frações de fósforo em estrumes e sua eficiência como adubo fosfatado. Revista Brasileira de Ciência do Solo, 25, 635-644. https://doi.org/10.1590/S0100-0683 2001000300012

Cavalaglio, G., Coccia, V., Cotana, F., Gelosia, M., Nicolini, A., \& Petrozzi, A. (2017). Energy from poultry waste: An Aspen Plus-based approach to the thermo-chemical processes. Waste Management, 73, 496-503. https://doi.org/10.1016/j.wasman.2017.05.037

Cavallari, M., Izquierdo, J., Braga, G., Dirani, E., Pereira-da-Silva, M., Rodríguez, E., \& Fonseca, F. (2015). Enhanced sensitivity of gas sensor based on poly(3-hexylthiophene) thin-film transistors for disease diagnosis and environment monitoring. Sensors, 15, 9592-9609. https://doi.org/10.3390/s150409592

Costa, A. C. S., \& Bigham, J. M. (2009). Óxidos de ferro. In V. F. Melo, \& R. F. Alleoni (Eds.), Quimica e mineralogia do solo. Viçosa: SBCS.

Cunha, E. de Q., Stone, L. F., Didonet, A. D., Ferreira, E. P. de B., Moreira, J. A. A., \& Leandro, W. M. (2011). Atributos químicos de solo sob produção orgânica influenciados pelo preparo e por plantas de cobertura. Revista Brasileira de Engenharia Agrícola e Ambiental, 15, 1021-1029. https://doi.org/10.1590/S1415-4366 2011001000005

Dai-Pra, M. A., Corrêa, E. K., Roll, V. F., Xavier, E. G., Lopes, D. C. N., Lourenço, F. F., ... Roll, A. P. (2009). Uso de cal virgem para o controle de Salmonella spp. e Clostridium spp. em camas de aviário. Ciência Rural, 39, 1189-1194. https://doi.org/10.1590/S0103-84782009005000028

Dias, N. da S., \& Blanco, F. F. (2010). Efeitos dos sais no solo e na planta. Manejo da Salinidade na Agricultura: Estudos básicos e aplicados.

EMBRAPA (Empresa Brasileira de Pesquisa Agropecuária). (1997). Manual de métodos de análise de solos (2nd ed., p. 212). Centro Nacional de Pesquisa de Solos. Rio de Janeiro: Embrapa.

EMBRAPA (Empresa Brasileira de Pesquisa Agropecuária). (2013). Sistema Brasileiro de Classificação de Solos (3rd ed., p. 353). Centro Nacional de Pesquisa de Solos. Brasília, DF: Embrapa.

Engel, R., Jones, C., \& Wallander, R. (2011). Ammonia volatilization from urea and mitigation by NBPT following surface application to cold soils. Soil Science Society of America Journal, 75, 2348-2357. https://doi.org/10.2136/sssaj2011.0229

Fontes, M. P. F., Camargo, O. A., \& Sposito, G. (2001). Eletroquímica das partículas coloidais e sua relação com a mineralogia de solos altamente intemperizados. Scientia Agricola, 58, 627-646. https://doi.org/10.1590/ S0103-90162001000300029

Forrest, A. L., Fattah, K. P., Mavinic, D. S., \& Koch, F. A. (2008). Optimizing struvite production for phosphate recovery in WWTP. Journal of Environmental Enginnering, 134, 395-402. https://doi.org/10.1061/(ASCE) 0733-9372(2008)134:5(395)

Freire, M. B. G. dos S., \& Freire, F. J. (2007). Fertilidade do solo e seu manejo em solos afetados por sais. In R. F. Novais, V. H. Alvarez, N. F. Barros, R. L. F. Fontes, R. B. Cantarutti, \& J. C. L. Neves (Eds.), Fertilidade do solo (pp. 929-951). Viçosa: Sociedade Brasileira de Ciência do Solo.

Gaind, S., \& Nain, L. (2010). Exploration of composted cereal waste and poultry manure for soil restoration. Bioresource Technology, 101, 2996-3003. https://doi.org/10.1016/j.biortech.2009.12.016

Garay, I., Kindel, A., Carneiro, R., Franco, A. A., Barros, E., \& Abbadie, L. (2003). Comparação da matéria orgânica e de outros atributos do solo entre plantações de Acacia mangium e Eucalyptus grandis. Revista Brasileira de Ciência do Solo, 27, 705-712. https://doi.org/10.1590/S0100-06832003000400015

Ghini, R., Schoenmaker, I. A. S., \& Bettiol, W. (2002). Solarização do solo e incorporação de fontes de matéria orgânica no controle de Pythium spp. Pesquisa Agropecuária Brasileira, 37, 1253-1261. https://doi.org/ 10.1590/S0100-204X2002000900008 
Gomes, P. C., Moura Filho, W., Costa, L. M., \& Fortes, M. P. F. (1994). Influência da cobertura vegetal na formação e evolução de húmus e sua relação com grau de floculação de um LATOSSOLO VERMELHO-Amarelo do Município de Viçosa, Minas Gerais. Revista Ceres, 41, 223-233.

Gonçalves, G. K., Meurer, E. J., Bortolon, L., \& Gonçalves, D. R. N. (2011). Relação entre óxidos de ferro e de manganês e a sorção de fósforo em solos no Rio Grande do Sul. Revista Brasileira de Ciência do Solo, 35, 1633-1639. https://doi.org/10.1590/S0100-06832011000500017

Heij, G. J., \& Schneider, T. (1995). Dutch priority programme on acidification (Final report, Report no. 300-05, p. 160). National Institute for Public Health and Environment, Bilthoven.

Hersztek, M. M., \& Baran, K. G. A. (2016). Effect of poultry litter biochar on soil enzymatic activity, ecotoxicity and plant growth. Applied Soil Ecology, 105, 144-150. https://doi.org/10.1016/j.apsoil.2016.04.006

Inal, A., Gunes, A., Sahin, O., Taskin, M. B., \& Kaya, E. C. (2015). Impacts of biochar and processed poultry manure, applied to a calcareous soil, on the growth of bean and maize. Soil Use and Management, 31, 106-113. https://doi.org/10.1111/sum.12162

Kiehl, J. C. (1997). Adubação orgânica de culturas forrageiras (pp. 208-250). Simpósio sobre ecossistemas de pastagens, 3, Jaboticabal. Anais... Jaboticabal: FCAV/UNESP.

Kingery, W. L., Wood, C. W., \& Delaney, D. P. (1993). Implications of long-term land application of poultry litter on tall fescue pastures. Journal of Production Agriculture Abstract-Research, 6, 390-395.

Lima, J. J. de, Mata, J. D. V. da, Pinheiro, N. R., \& Scapim, C. A. (2007). Influência da adubação orgânica nas propriedades químicas de um Latossolo Vermelho distrófico e na produção de matéria seca de Brachiaria brizantha cv. Marandu. Acta Scientiarum Agronomy, 29, 715-719.

Lupton, S. (2017). Markets for waste and waste derived fertilizers: An empirical survey. Journal of Rural Studies, 55, 83-99. https://doi.org/10.1016/j.jrurstud.2017.07.017

Magalhães, J. L., Simon, G. A., Menezes, J. F. S., Rodrigues, A. A., Azambuja, U. S., Rodrigues, D. A., \& Costa, A. C. S. da. (2016). Growth of eucalyptus seedlings irrigated with diferente wastewaters. African Journal of Agricultural Research, 11, 4779-4785. https://doi.org/10.5897/AJAR2016.11869

Malavolta, E. (1979). ABC da Adubação (4th ed., p. 255). São Paulo SP, Editora Agronomia Ceres.

Malavolta, E., Vitti, G. C., \& Oliveira, S. A. (1997). Avaliação do estado nutricional de plantas: Princípios e aplicações (2nd ed., p. 319). Piracicaba: Potafos.

Marschner, H. (1995). Mineral nutritional of higher plants (p. 889). London: Academic.

Mcbratney, A. B., Minasny, B., Cattle, S. R., \& Vervoort, R. W. (2002). From pedotranfer functions to soil inference systems. Geoderma, 109, 41-73. https://doi.org/10.1016/S0016-7061(02)00139-8

Mello, S. C., \& Vitti, G. C. (2002). Desenvolvimento do tomateiro e modificações nas propriedades químicas do solo em função da aplicação de resíduos orgânicos, sob cultivo protegido. Horticultura Brasileira, 20, 200-206. https://doi.org/10.1590/S0102-05362002000200017

Melo, W. J., Marques, M. O., Santiago, G., Cheli, R. A., \& Leite, S. A. S. (1994). Efeito de doses crescentes de lodo de esgoto sobre frações da matéria orgânica e CTC de um Latossolo cultivado com cana-de-açúcar. Revista Brasileira de Ciência do Solo, 18, 449-455.

Mendonça, E. S., Rowell, D. L., Martins, A. G., \& Silva, A. P. (2006). Effect of pH on the development of acidic sites in clayey and sandy loam Oxisol from the Cerrado Region, Brazil. Geoderma, 132, 131-142. https://doi.org/10.1016/j.geoderma.2005.05.001

Menezes, J. F. S., Alvarenga, R. C., Silva, G. P., Konzen, E. A., \& Pimenta, F. F. (2004). Cama de frango na agricultura: perspectivas e viabilidade técnica econômica (Boletim Técnico 3). Rio Verde: FESURV.

Nachtigall, G. R., Nogueirol, R. C., \& Alleoni, L. R. F. (2009). Extração seqüencial de Mn e Zn em solos em função do pH e adição de cama-de-frango. Revista Brasileira de Engenharia Agrícola e Ambiental, 13, 240-249. https://doi.org/10.1590/S1415-43662009000300004

Netto, A. O. A., Gomes, C. S. G., Lins, C. C. V., Barros, A. C., Campeche, L. F. S. M., \& Blanco, F. F. (2007). Características químicas e salino-sodicidade dos solos do Perímetro Irrigado Califórnia, SE, Brasil. Ciência Rural, 37, 1640-1645. https://doi.org/10.1590/S0103-84782007000600021 
Neves, L. S. das, Ernani, P. R., \& Simonete, M. A. (2009). Mobilidade de potássio em solos decorrente da adição de doses de cloreto de potássio. Revista Brasileira de Ciência do Solo, 33, 25-32. https://doi.org/ $10.1590 / \mathrm{S} 0100-06832009000100003$

Oliveira, F. C., Mattiazzo, M. E., Marciano, C. R., \& Abreu, Jr. C. H. (2002). Alterações em atributos químicos de um Latossolo pela aplicação de composto de lixo urbano. Pesquisa Agropecuária Brasileira, 37, 529-538. https://doi.org/10.1590/S0100-204X2002000400015

Omari, R. A., Aung, H. P., Hou, M., Yokoyama, T., Onwona-Agyeman, S., Oikawa, Y., ... Bellingrath-Kimura, S. D. (2016). Influence of Different Plant Materials in Combination with Chicken Manure on Soil Carbon and Nitrogen Contents and Vegetable Yield. Pedosphere, 26, 510-521. https://doi.org/10.1016/S1002-0160(15) 60061-3

Pessoa, L. G. M., Oliveira, E. E. M., Freire, M. B. G. dos S., Freire, F. J., Miranda, M. A., \& Santos, R. L. dos. (2010). Composição química e salinidade do lixiviado em dois solos cultivados com cebola irrigada com água salina. Revista Brasileira de Ciências Agrárias, 5, 406-412. https://doi.org/10.5039/agraria.v5i3a573

Possamai, A. J., Freiria, L. B. da, Barboza, A. C., Silva, P. I. L. da R., \& Zervoudakis, J. T. (2014). Influência da adubação fosfatada e calagem na ecofisiologia de gramíneas forrageiras. Pubvet, 8.

Raij, B. V., Andrade, J. C., Cantarella, H., \& Quaggio, J. A. (2001). Análise química para avaliação da fertilidade de solos tropicais. Campinas: Instituto Agronômico de Campinas.

Richart, A., Gibbert, R. M., \& Müller, E. J. (2014). Perdas de nitrogênio por volatilização de amônia da cama de aviário em função do manejo de aplicação em ARGISSOLO VERMELHO. Synergismus Scyentifica, 9, 1-7.

Ritter, W. F., \& Chirnside, A. E. M. (1987). Influence of Agricultural Practices on Nitrates of the Water Table Aquifer. Biological Wastes, 19, 165-178. https://doi.org/10.1016/0269-7483(87)90050-4

Ronquim, C. C. (2010). Conceitos de fertilidade do solo e manejo adequado para as regiões tropicais (Embrapa Monitoramento por Satélite, Boletim de Pesquisa e Desenvolvimento, 8). Campinas: Embrapa Monitoramento por Satélite.

Santos, C. C., Bellingieri, P. A., \& Freitas, J. C. de. (2004). Efeito da aplicação de compostos orgânicos de cama de frango nas propriedades químicas de um LATOSSOLO VERMELHO escuro cultivado com sogro granífero. Científica, 32, 134-140.

SAS. (2001). SAS User's Guide. SAS Institute, Inc., Cary, NC.

Savory, B. M. (1962). Boron deficiency in Eucalyptus in Norther Rhodesia. Empire Forest Review, 41, 118-125.

Schindler, D. W. (1978). Factors regulating phytoplankton production and standing crop in the world's fresh waters. Limnology and Oceanography, 23, 486-478. https://doi.org/10.4319/lo.1978.23.3.0478

Schuiling, R. D., \& Anrade, A. (1999). Recovery of struvite from calf manure. Environmental Technology, 20, 765-768. https://doi.org/10.1080/09593332008616872

Serrano, J. M., Peca, J. O., Silva, J. R., \& Shahidian, S. (2010). Medição e mapeamento da condutividade eléctrica aparente do solo em pastagens. Revista de Ciências Agrárias, 33, 5-14.

Silva, A. de A., Costa, A. M. da, Lana, R. M. Q., Ângela, M. Q., \& Lana, A. M. Q. (2012). Recycling of nutrients with application of organic waste in degraded pasture. Engenharia Agricola, 32, 405-414. https://doi.org/10.1590/S0100-69162012000200020

Silva, E. B., Costa, H. A. O., \& Farnezi, M. M. F. (2006). Acidez potencial estimada pelo método do ph smp em solos da região do vale do Jequitinhonha no estado de minas gerais. Revista Brasileira de Ciência do Solo, 30, 7511-757. https://doi.org/10.1590/S0100-06832006000400016

Silva, F. C. da. (2009). Análise química de tecido vegetal. In: Manual de Análises Químicas de Solo, Plantas e Fertilizantes (2nd ed., pp. 193-204). Brasília: Embrapa Informação Tecnológica.

Silva, F. de A. S. (2015). ASSISTAT: Versão 7.7 Beta. DEAG-CTRN-UFCG.

Silva, I. R. da, \& Mendonça, E. de S. (2007). Matéria orgânica do solo. In R. F. Novais, V. Alvarez, V. H. Barros, N. F. Fontes, R. L. F. Cantarutti, \& R. B. Neves (Eds.), Fertilidade do solo (pp. 275-357). Viçosa: Sociedade Brasileira de Ciência do Solo.

Silva, M. O., Freire, M. B. G. dos S., Mendes, A. M. S., Freire, F. J., Sousa, C. E. S., \& Góes, G. B. (2008). Crescimento de meloeiro e acúmulo de nutrientes na planta sob irrigação com águas salinas. Revista Brasileira de Engenharia Agrícola e Ambiental, 12(6). https://doi.org/10.1590/S1415-43662008000600005 
Silveira, R. L. V. de A., Casarin, V., Paula, T. de A., \& Silveira, R. I. (2007). Nutrição e adubação com boro em Eucalyptus (Boletim Técnico). Piracicaba: Agroflorestal.

Soares, C. R. F. S., Siqueira, J. O., Carvalho, J. G. de, Moreira, F. M. S., \& Grazziotti, P. H. (2000). Crescimento e nutrição mineral de Eucalyptus maculata e Eucalyptus urophylla em solução nutritiva com concentração crescente de cobre. Revista Brasileira de Fisiologia Vegetal, 12, 213-225. https://doi.org/10.1590/ S0103-31312000000300005

Soares, J. R., Cantarella, H., \& Menegale, M. L. C. (2012). Ammonia volatilization losses from surface-applied urea with urease and nitrification inhibitors. Soil Biology and Biochemistry, 52, 82-89. https://doi.org/ 10.1016/j.soilbio.2012.04.019

Soares, M. R., Casagrande, J. C., \& Alleoni, L. R. F. (2008). Adsorção de boro em solos ácricos em função da variação do pH. Revista Brasileira de Ciência do Solo, 32, 111-120. https://doi.org/10.1590/S0100-068320 08000100011

Sousa, D. M. G., \& Lobato, E. (2004). Cerrado: correção do solo e adubação (2nd ed., p. 416). Brasília: Embrapa Cerrados.

Teixeira, I. R., Souza, C. M. de, Borém, A., \& Silva, G. F. da. (2003). Variação dos valores de pH e dos teores de carbono orgânico, cobre, manganês, zinco e ferro em profundidade em Argissolo Vermelho-Amarelo, sob diferentes sistemas de preparo do solo. Bragantia, 62, 119-126. https://doi.org/10.1590/S0006-870520030 00100015

Termeer, W., \& Warman, P. (1993). Use of mineral amendments to reduce ammonia losses from dairy-cattle and chicken-manure slurries. Bioresources Technology, 44, 217-222.

Turner, D. A., Edis, R. B., Chen, D., Freney, J. R., Denmead, O. T., \& Christie, R. (2010). Determination and mitigation of ammonia loss from urea applied to winter wheat with $\mathrm{N}$-(n-butyl) thiophosphorictriamide. Agriculture, Ecosystems \& Environment, 137, 261-266.

Vail, J. W., Calton, W. E., \& Strang, R. M. (1957). Dieback of wattle: Boron deficiency. The East African Agricultural Journal, 23, 100-103.

Zahan, Z., Georgiou, S., Muster, T. H., \& Othman, M. Z. (2018). Semi-continuous anaerobic co-digestion of chicken litter with agricultural and food wastes: A case study on the effect of carbon/nitrogen ratio, substrates mixing ratio and organic loading. Bioresource Technology, 270, 245-254.

Zanão-Júnior, L. A., Lana, R. M. Q., \& Guimarães, E. C. (2007). Variabilidade espacial do pH, teores de matéria orgânica e micronutrientes em profundidades de amostragem num Latossolo Vermelho sob semeadura direta. Ciência Rural, 37, 1000-1007.

\section{Copyrights}

Copyright for this article is retained by the author(s), with first publication rights granted to the journal.

This is an open-access article distributed under the terms and conditions of the Creative Commons Attribution license (http://creativecommons.org/licenses/by/4.0/). 